\title{
The Influence of Satisfaction on Service Quality and Trust in Products on Loyalty of Bank Rakyat Indonesia Credit Cards Users in Padang Panjang
}

\author{
Azwar Azwar', Susi Evanita ${ }^{2}$, Abror Abror ${ }^{3}$ \\ ${ }^{1}$ Universitas Negeri Padang, Padang, Indonesia, $\triangle$ azwarpp1978@gmail.com \\ 2 Universitas Negeri Padang, Padang, Indonesia, $₫$ susievanita@gmail.com \\ ${ }^{3}$ Universitas Negeri Padang, Padang, Indonesia, $₫$ abror094@gmail.com
}

\begin{abstract}
This study aims to explain the influence of satisfaction on service quality towards trust in products and customer loyalty of Bank Rakyat Indonesia credit card users in Padang Panjang City and the extent to which trust in products has an effect on customer loyalty of Bank Rakyat Indonesia credit card users in Padang Panjang city. The sample of this study was users of Bank Rakyat Indonesia credit card in Padang Panjang city with a total sample of 192 respondents. The analysis technique used in this study is SEM analysis. The results of the study show that: (1) satisfaction on service quality has a positive and significant effect on trust in the product; (2) satisfaction on service quality and trust in products has a positive and significant effect on the loyalty of Bank Rakyat Indonesia credit card users in Padang Panjang
\end{abstract}

Keywords: satisfaction, service quality, trust, loyalty

\section{Introduction}

Customer loyalty must be built with hard work in the form of personalization where customers become the core of marketing activities. Customers who have the intention to reuse and recommend products and services to others are most likely loyal customers. By increasing the continuity of relationships with old customers and continuing to acquire new customers with the concept of customer loyalty, it will have a greater influence than the market share, because the business strategy is focused on the permanence and satisfaction of each customer.

Customer loyalty can be influenced by satisfaction with service quality. Demir, (2015) research shows that satisfaction with service quality seen from empathy, responsiveness, assurance, reliability, and tangible influences customer loyalty. The actual conditions in the field also show that credit card offered to consumers who already have a credit card. For credit card issuing banks, especially those that have a big name or status as a state-owned enterprise (BUMN), a record of track records in debt is considered important for someone who will apply for credit card ownership. Some previous studies show that there is an influence between satisfaction and trust. Maria (2014) shows that satisfaction with good service has an effect on trust seen from the belief in service delivery, product quality, and the accuracy of the promises delivered. In line with the Han (2017) research, there is an influence between satisfaction with trust. Customer satisfaction variables and service quality variables indeed have a lot of research discussing it but in this study, researchers focused on discussing customer satisfaction on the quality of services provided by the company in one variable.

For some people, credit cards even support their lifestyle and are used in almost all purchases of goods or services. Although credit cards have become a lifestyle for some people, there are still many who don't believe in having a credit card. The main reason is because their bad perception on credit cards will only add to the financial burden. The notion of credit cards often plunges people into debt bondage, especially if they don't understand how to use them is a credit card trust factor.

The existence of a credit card is well known by the society. However, there are still many consumers who have not used a credit card, even refusing to own the card. Credit cards even become an inseparable part of the lives of some people who live in urban areas. Don't be surprised if you see people who have more than one credit card, the more credit cards they have, the more proud the 
credit card owner is. Credit cards can make consumers' lives more comfortable if they are able to manage them, but it can also be transformed into a disaster if they have to bear unnecessary costs, such as costs due to late payment of bills. Variables of customer trust and product variables have many previous studies that discussed, but in this study the researcher set the focus of variables in discussing customers' trust in the products offered in one variable.

Customer loyalty can be influenced by trust in products based on the results of the research of Ziaullah(2014) shows that products can determine satisfaction that will affect customer loyalty. Products here are seen from the type of product, product quality, product availability, product reliability, product delivery, and packaging. Trust can also be determined by product quality that can affect loyalty (Brilliant, 2013).

This study discusses whether the satisfaction factor for service quality and trust influences the loyalty of Bank Rakyat Indonesia credit card users in Padang Panjang City. This study aims to determine the influence of satisfaction with service quality and loyalty of credit users of Bank Rakyat Indonesia credit cards using data from 2012 - 2016 in the City of Padang Panjang. The expected contribution of this research is being able to show the relationship between satisfaction on service quality and trust with the loyalty of Bank Indonesia credit card users in Padang Panjang City. This will be a consideration in determining the strategy of the issuing bank. In connection with this, the authors are interested in conducting research with the title: "The Influence of Satisfaction on Service Quality and Trust in Products towards the Loyalty of Users of Bank Rakyat Indonesia Credit Cards in Padang Panjang City"

\section{Methods}

This research uses quantitative research methods. This study aims to explain the influence of satisfaction with service quality on trust in products and customer loyalty of Bank Rakyat Indonesia credit card users in Padang Panjang City and the extent to which trust in products has an effect on customer loyalty of Bank Rakyat Indonesia credit card users in Padang Panjang City. The sample of this study was a user of Bank Rakyat Indonesia credit card in Padang Panjang City with a total sample of 192 respondents. The technique of determining the sample in this study is using accidental sampling technique (convenience sampling).

The instrument used in this study is using questionnaires, which are then distributed to customers selected as respondents. Before the questionnaire was distributed to respondents, the questionnaire was first tested for validity, and reliability, of each variable studied. The data analysis technique used is SEM (Structural Equation Modeling).

Table 1 Validity and Reliability Test Results

\begin{tabular}{cccc}
\hline Variable & $\begin{array}{c}\text { Validity } \\
\text { (r value) }\end{array}$ & $\begin{array}{c}\text { Reliability } \\
\text { (Cronbach's Alpha) }\end{array}$ & Result \\
\hline Satisfaction on Service Quality & $0,380-0,763$ & 0,922 & Valid and Reliable \\
\hline Trust in Products & $0,570-0,788$ & 0,902 & Valid and Reliable \\
\hline Loyalty & $0,118-0,790$ & 0,827 & 2 item dismissed \\
\hline
\end{tabular}

Source: Processed Primary Data, 2019

\section{Results and Discussion}

\section{Data Analysis}

This analysis is used to determine the structural relationship between the variables studied. Structural relations that occur between variables can be tested for their suitability with the goodness of fit index. The results of SEM analysis in this study can be seen in the following figure: 


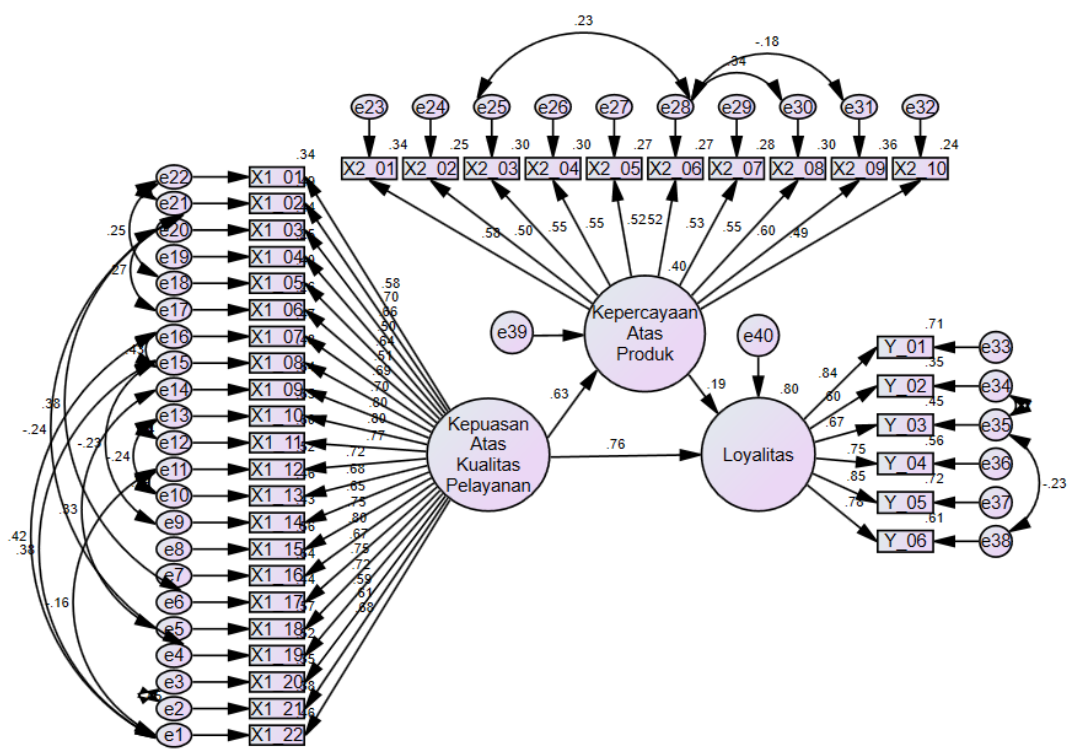

Figure 1 Full Model Structural Equation Model (SEM) Test Results

From the picture above the Goodness of Fit value of the full SEM model can be seen in the Table below:

Table 2 Full Model Goodness of Fit SEM Test

\begin{tabular}{lrrl}
\hline Goodness of Index & Cut-off Value & Model Result & \multirow{2}{*}{ Annotation } \\
\hline Chi Square & Expected small & 1231,828 & \\
\hline RMSEA & $\leq 0,08$ & 0,069 & Fit \\
\hline CMIN/DF & $\leq 2,00$ & 1,919 & Fit \\
\hline TLI & $\geq 0,90$ & 0,852 & Not fit \\
\hline CFI & $\geq 0,95$ & 0,864 & Not Fit \\
\hline PCFI & $>0,60$ & 0,789 & Fit \\
\hline
\end{tabular}

Sourced: Processed Primary Data, 2019

Table 2 shows the chi square results of 1231.828 , the RMSEA value is $0.069 \leq 0.08$, the CMIN / DF value is $1.919 \leq 2$, the TLI value is $0.852<0.95$, the CFI value is $0.864<0.95$, and the PCFI value of $0,789>0,6$ which indicates that the suitability test of the model is not good, so it needs to be modified so that the model can be categorized as fit. Modifications are carried out several times with the aim of obtaining values that are in accordance with the reference values of the structural model. The final model produced is in the following picture:

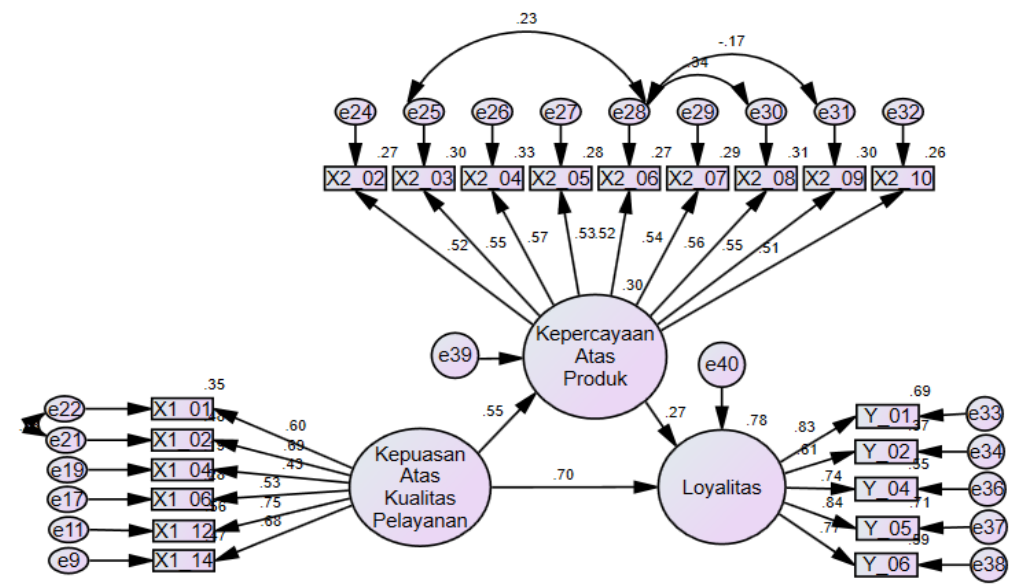

Figure 2 Full Model Structural Equation Modeling (SEM) Test Results After Modification 
From figure 2 above the value of the Goodness of Fit of the full SEM model can be seen in the Table below:

Table 3 Full Model Goodness of Fit SEM Test

\begin{tabular}{lcrl}
\hline Goodness of Index & Cut-off Value & Model & Annotation \\
\hline Chi Square & Expected small & 229,465 & \\
\hline RMSEA & $\leq 0,08$ & 0,046 & Fit \\
\hline CMIN/DF & $\leq 2,00$ & 1,408 & Fit \\
\hline TLI & $\geq 0,90$ & 0,943 & Fit \\
\hline CFI & $\geq 0,95$ & 0,951 & Fit \\
\hline PCFI & $>0,60$ & 0,816 & Fit \\
\hline
\end{tabular}

Source: Processed Primary Data, 2019

Table 3 shows the chi square result of 229.465, the RMSEA value is $0.046 \leq 0.08$, the CMIN / DF value is $1.408 \leq 2$, the TLI value is $0.943>0.90$, the CFI value is $0.951>0.95$, and the PCFI value is 0.816 $>0.6$ which indicates that the model conformity test meets the criteria for model fit.

\section{Hypothesis testing}

Hypothesis testing is done to determine whether or not the independent variables influence the dependent variable. Previously, we could know the effect of exogenous variables on endogenous variables from the table below:

Table 4 Inter -Variable Influence

Standardized Regression Weights: (Group number 1 - Default model)

\begin{tabular}{lclr}
\hline & & & Estimate \\
\hline Trust onProduct & $<---$ & SatisfactiononServiceQuality & .545 \\
\hline Loyalty & $<--$ & Trust on Product & .274 \\
\hline Loyalty & $<---$ & Satisfaction onServiceQuality & .703 \\
\hline Source: Processed Primary Data, 2019 & &
\end{tabular}

Satisfaction with service quality has a positive and significant effect on trust in the product

Based on data from the results of data processing it is known that the $\mathrm{P}$ value (probability) is 0,000. H0 is rejected and Ha is accepted. So that it can be concluded that the first hypothesis in this study is acceptable. This means that satisfaction with service quality has a positive and significant effect on trust in products

\section{Satisfaction with service quality has a positive and significant effect on loyalty}

Based on data from the results of data processing it is known that the $\mathrm{P}$ value (probability) is 0,000. H0 is rejected and Ha is accepted. So it can be concluded that the second hypothesis in this study is acceptable. This means that satisfaction with service quality has a positive and significant effect on loyalty

\section{Trust in products has a positive and significant effect on loyalty}

Based on data from the results of data processing, it is known that the $\mathrm{P}$ value (probability) is 0.001. H0 is rejected and Ha is accepted. So that it can be concluded that the third hypothesis in this study is acceptable. This means that trust on the product has a positive and significant effect on loyalty

\section{Discussion}

The first hypothesis examines the effect of satisfaction with service quality on trust in Bank Rakyat Indonesia (BRI) credit card products in Padang Panjang city. Satisfaction with service quality has a positive and significant effect on the trust worthiness of Bank Rakyat Indonesia (BRI) credit card 
products in Padang Panjang city. This is consistent with the results of the study Sultan (2018) that there is an influence of satisfaction with trust. Then the results of research Han (2017) and Faizal (2017) show there is an influence between satisfaction with trust. In line with Unidha (2017) research shows that service quality has a significant effect on customer's trust. This result can be explained that the customer will believe in the company if the quality of service received is in accordance with the wishes of the customer. Service quality is a form of customer assessment of the level of service received (perceived service) with the expected level of service. In this study the higher the satisfaction with the quality of service, the higher the trust in the credit card products of Bank Rakyat Indonesia (BRI) in Padang Panjang city.

Several other previous studies show that there is an influence between satisfaction with trust. Maria (2014) research shows that satisfaction with good service has an effect on trust seen from the trust in service delivery, product quality, and the accuracy of the promises delivered. Furthermore, the results of the study Moreira (2015) show that trust arising from the service quality influences trust in the services provided. Roostika (2011) shows that there is an indirect relationship between service quality and loyalty through trust.

Satisfaction with service quality affects the trust of the product. If the company is able to provide qualify services, the company has built one of the foundations to create customer satisfaction. Satisfaction with the quality of service will make customers return to transact with the company and then will create a sense of security for the customers so as to make confidence in the products offered by the company.

Consumers' trust or consumers' knowledge concerns the belief that a product has various attributes, and benefits from these various attributes. The higher the level of trust the user has in the product/service, the more likely they will feel comfortable using the product/service and will be involved in ranking positive products/services (Hui, 2014). If customers have had satisfied with the company's products, they will form a higher trust in their products (Chen, 2013).

Based on the results of the analysis on the satisfaction with service quality variable, shows indicators that have the highest achievement level of respondents in the indicator of reliability. But the reliability indicator still has the achievement level of respondents in the adequate category. That is, there needs to be an increase in customer satisfaction on reliability or BRI's reliability in providing services such as being satisfied with BRI's explanation of credit cards, satisfied with BRI's promised services, satisfied with services providied by BRI, satisfied with BRI's operational hours, and satisfied with the way employees give service. While the indicators with the lowest achievement level of respondents is assurance, which has level of respondents' in the adequate category. This means that the customer is not fully satisfied with the assurance or guarantee provided by BRI. Assurance is determined from being satisfied on BRI credit card security, satisfied on guaranteeing the use of BRI credit cards, and satisfied with the competence of BRI employees. If each indicator of satisfaction with service quality is increased, it can increase the trust in Bank Rakyat Indonesia (BRI) credit card products in Padang Panjang city.

The second hypothesis examines the influence of satisfaction on the service quality towards the loyalty of Bank Rakyat Indonesia (BRI) credit card customers in Padang Panjang city. The results of the analysis show that satisfaction with service quality has a positive and significant effect on the loyalty of credit card users of Bank Rakyat Indonesia (BRI) in Padang Panjang city. Better service quality tends to build satisfaction and loyalty among customers. Service quality aspects (i.e. physical environment, customer-friendly environment, responsiveness, communication, privacy and safety) are positively related to loyalty mediated through satisfaction (Fatima, 2018). Service quality plays an important role in increasing customer satisfaction and will ultimately make consumers loyal to use the services of the company (Setiawan, 2017). Then the research results (Demir, 2015) which show that satisfaction with service quality seen from empathy, responsiveness, assurance, reliability, and tangible influences customer loyalty. The company can also increase satisfaction with service quality with customer trust (Akbar, 2009). In this research, the higher the satisfaction of the service quality, the higher the loyalty of credit card users of Bank Rakyat Indonesia (BRI) in Padang Panjang city. 
According to Yoo (2013) Customer loyalty is described as a repeat customer visit or repeat buying behavior, including emotional commitment or expression of a good attitude towards the service provider. Customer loyalty is defined as the interaction between the customer's relative behavior towards the brand or company, and their repeat buying behavior towards the brand or company. Customer loyalty is measured using parameters such as the customer's wish and intentions to buy in the future and their chosen behavior (Noyan, 2014).

Satisfaction with service quality influences the loyalty of BRI credit card users in Padang Panjang city. Satisfaction is the result of an assessment of credit card users that the service quality has provided more levels of fulfillment. Credit card users are satisfied if their expectations are met or will be very satisfied if their expectations are exceeded. Loyalty has a causal relationship with satisfaction with service quality. The occurrence of loyalty is due to the influence of satisfaction or dissatisfaction of credit card users to the service quality that accumulate continuously.

Based on the results of the analysis on the satisfaction e on service quality variable shows indicators with the lowest achievement level of respondents, namely assurance, which has a achievement level of respondents in adequate categories. This means that the customer is not fully satisfied with the assurance or guarantee provided by BRI. Assurance is determined from being satisfied on BRI credit card security, satisfied on of BRI credit cards use guaranteed, and satisfied with the competence of BRI employees. If this indicator is improved, it can increase customer loyalty of Bank Rakyat Indonesia (BRI) credit cards in Padang Panjang city.

The second hypothesis examines the influence of trust in products towards the loyalty of Bank Rakyat Indonesia (BRI) credit card users in Padang Panjang city. The results of the analysis show that trust in the product has a positive and significant effect on the loyalty of the credit card users of Bank Rakyat Indonesia (BRI) in Padang Panjang city. Satisfaction has a positive impact on customer trust, and customer trust has a significant impact on loyalty (Bhat, 2018). In addition, trust mediates the effect of knowledge and satisfaction towards loyalty. Customer trust is an important characteristic of each relationship. Customer loyalty produces good and awesome feelings about the company in the minds of customers (Sarwar, 2012). The product can determine satisfaction that will affect customer loyalty (Ziaullah, 2014). Products here are seen from the type of product, product quality, product availability, product reliability, product delivery, and packaging. Trust can also be determined by product quality that can affect loyalty (Brilliant, 2013). Trust is a special psychological state that can only occur in certain relationships. In this study, the higher the trust in the product, the higher the loyalty of the credit card users of Bank Rakyat Indonesia (BRI) in Padang Panjang city.

Trust in products affects the loyalty of BRI credit card users in Padang Panjang city. In creating credit card user loyalty through trust, it can be built through the product. Credit card products provided by banks have an influence on the formation of trust in credit card users that will also affect loyalty. According to Pan (2012) Customer loyalty is the company's most enduring asset. By creating and maintaining customer loyalty, the company develops long-term, mutually beneficial relationships with customers. Every company is interested in fundamental questions about the concept of customer loyalty, for example, the driving force of loyal customer's behaviour.

Based on the results of the achievement level of respondents on each indicator of trust in the product, it shows that the benevolence indicator has the highest achievement level of respondent, but is still in category adequate. This means the need to improve benevolence indicators such as serving in the best interests of customers, doing the best to help customers, and providing bonuses/rewards. While indicator with the lowest achievement level of respondents is integrity, which is in the adequate category. This means that trust in BRI's integrity still needs to be improved such as being honest in establishing relationships with customers, being honest with customers, and being able to maintain commitment to customers. If each indicator of trust in the product is increased, it will increase the loyalty of Bank Rakyat Indonesia (BRI) credit card customers in Padang Panjang city. 


\section{Conclusions}

Based on the results of research and hypothesis testing, conclusions can be taken in this study are: (1). Satisfaction on service quality has a positive and significant effect on trust in the product. That is, satisfaction with service quality in the form of tangibles, reliability, responsiveness, assurance, and empathy, can increase the trust in the products of Bank Rakyat Indonesia credit card users in Padang Panjang city; (2). Satisfaction on service quality has a positive and significant effect on loyalty. This means that satisfaction with service quality in the form of tangibles, reliability, responsiveness, assurance, and empathy can increase the loyalty of Bank Rakyat Indonesia credit card users in Padang Panjang city; (3). Trust in products has a positive and significant effect on loyalty. That is, trust in products in the form of ability, integrity and benevolence can increase the loyalty of Bank Rakyat Indonesia credit card users in Padang Panjang city.

Based on the findings in this study, recommending the management of Bank Rakyat Indonesia in Padang Panjang city to increase the loyalty of Bank Rakyat Indonesia credit card users in Padang Panjang city can be determined by the following.

Increasing satisfaction with the service quality by improving the assurance or guarantees of Bank Rakyat Indonesia in Padang Panjang city to customers by providing guarantees in the use of BRI credit cards such as certainty of receipt of BRI credit cards at many merchants or shopping venues, continuously increasing credit card security, that is using of the system of the latest security, and enhance the competence of BRI employees in serving customers such as providing training or skills to employees. Then increase tangibles or physical evidence of Bank Rakyat Indonesia in Padang Panjang city by re-evaluating and improving BRI's physical form visually such as improving the room design or outside appearance of the BRI building so that it is more attractive, using the latest technology such as the use of the latest satellites to prevent signal interference, enhances the appearance of BRI employees by displaying a more professional impression such as using the latest designs, and employees who are clear in providing information to customers by providing training to employees. Furthermore, increasing the responsiveness of Bank Rakyat Indonesia in Padang Panjang city by increasing the speed of employees in providing services and handling customer problems by providing training to employees so that serving customers improved, sending reports on time by providing real time descriptions of transactions to customers in various features both online and offline, and improve the current queue system such as adding counters in serving customers. Then increasing empathy of Bank Rakyat Indonesia in Padang Panjang city by providing credit card facilities in accordance with what was promised and according to customer needs, which is asking and analyzing customer needs in the use of credit cards so that the card used by the customer according to their needs, increases employee politeness by provide training to employees, and provide products according to customer needs, adjusting credit card limits to the needs and capabilities of customers. Furthermore, increasing the reliability of Bank Rakyat Indonesia in Padang Panjang city through BRI's operational hour timely, by providing discipline training to employees, providing services as promised, by preventing service failures or operational disruptions, providing reliable BRI services, by always adjusting customer needs that are always changing and diverse with the products offered, adjusting the way employees provide services to customers in accordance with the conditions and needs of customers and providing an explanation of credit cards properly so that training is needed in serving customers and consistent in implementing BRI operational standards.

In enhancing trust in products by increasing integrity or fulfilling customer desires and maintaining the integrity of Bank Rakyat Indonesia in Padang Panjang city by establishing relationships with customers and maintaining commitment to customers such as always giving real time reports to customers and delivering tariffs or service fees clearly. For this reason, BRI always asks about customer needs, desires and complaints so that customers become more committed to using BRI credit cards and BRI services can continue to be improved. Increasing the product ability of Bank Rakyat Indonesia in Padang Panjang city. For this reason, a more effective marketing strategy is needed to attract customer interest and demonstrate the advantages of BRI credit cards compared to other banks. In addition, BRI should always use the latest technology in managing customers and 
minimize operational disruptions such as being unable to make transactions due to signals or equipment damage. Furthermore, increasing benevolence of the products of Bank Rakyat Indonesia in Padang Panjang city by serving well each customer's interests and needs, and providing bonuses/rewards to customers such as giving prizes for certain transactions either physically or free of transaction fees or discounted prices for purchases using BRI credit cards. Then give prizes to loyal customers such as giving prizes based on the length of time being a BRI customer, and other rewards that can keep the customer from becoming a BRI credit card customer.

\section{References}

Akbar, M. M., \& Parvez, N. (2009). Impact Of Service Quality, Trust, And Customer Can Service Quality, Trust, And Customer Satisfaction On Customers Loyalty Satisfaction Engender Customers Loyalty.ABAC Journal, 29 (1), 24 - 38.

Bhat, S. A., Darzi, M. A., \& Parrey, S. H. (2018). Antecedents of Customer Loyalty in Banking Sector: A Mediational Study. The Journal for Decision Makers, 43 (2), 92 - 105. https://doi.org/10.1177/0256090918774697

Brilliant, M. A., \& Achyar, A. (2013). The Impact of Satisfaction and Trust on Loyalty of E-Commerce Customers. Asean Marketing Journal, 5 (1), 51 - 58.

Chen, Y. (2013). The influences of green perceived quality, green perceived risk, and green satisfaction. Management Decision, 51 (1), 63 - 82. https://doi.org/10.1108/00251741311291319

Demir, A. (2015). The Relations among Dimensions of Service Quality, Satisfaction, Loyalty, and Willingness to pay more: Case of GSM Operators Service at. International Journal of Academic Research in Accounting, Finance and Management Sciences, 5 (4), 146 - 154. https://doi.org/10.6007/IJARAFMS/v5-i4/1910

Faizal, K., \& Tan, F. B. (2017). The mediating role of trust and commitment on members' continuous knowledge sharing intention: A commitment-trust theory perspective International Journal of Information Management The mediating role of trust and commitment on members' continuous knowl. International Journal of Information Management, 35 (2), 145 - 151. https://doi.org/10.1016/j.ijinfomgt.2014.11.001

Fatima, T., Malik, S. A., \& Shabbir, A. (2018). Hospital Healthcare Service Quality, Patient Satisfaction and Loyalty: An Investigation in context of Private Healthcare Systems International Journal of Quality \& Reliability Management Article information: International Journal of Quality \& Reliability Management, 35 (6), 1196 - 1214. https://doi.org/10.1108/IJQRM-02-2017-0031

Han, H., \& Sean, S. (2017). Customer retention in the medical tourism industry: Impact of quality, satisfaction, trust, and price reasonableness Customer retention in the medical tourism industry : Impact of quality, satisfaction, trust, and price reasonableness. Tourism Management, 46 (February 2015), 20 - 29. https://doi.org/10.1016/j.tourman.2014.06.003

Hui, C., \& Cao, Y. (2014). Examining We Chat users' motivations, trust, attitudes, and positive wordof-mouth:Evidence from China. Computers In Human Behavior, 41, 104 - 111. https://doi.org/10.1016/j.chb.2014.08.013

Maria, S., Loureiro, C., Miranda, F. J., \& Breazeale, M. (2014). Who needs delight ? The greater impact of value, trust and satisfaction in utilitarian, frequent-use retail. Journal of Service Management, 25 (1), 101 - 124. https://doi.org/10.1108/JOSM-06-2012-0106

Moreira, A. C., \& Silva, P. M. (2015). The trust-commitment challenge in service quality-loyalty relationships International Journal of Health Care Quality Assurance Article information: International Journal of Health Care Quality Assurance, 28 (3), 253 - 266. https://doi.org/10.1108/IJHCQA-02-2014-0017

Noyan, F., \& Gölba, G. (2014). The antecedents of customer loyalty Fatma. Social and Behavioral Sciences, 109, 1220 - 1224. https://doi.org/10.1016/j.sbspro.2013.12.615

Pan, Y., Sheng, S., \& Xie, F. T. (2012). Journal of Retailing and Consumer Services Antecedents of customer loyalty: An empirical synthesis and reexamination. Journal of Retailing and Consumer Services, 19 (1), 150 - 158. https://doi.org/10.1016/j.jretconser.2011.11.004 
Roostika, R. (2011). The Effect of Perceived Service Quality and Trust on Loyalty: Customer's Perspectives on Mobile Internet Adoption. International Journal of Innovation, Management and Technology, 2 (4), 286 - 291.

Sarwar, M. Z., Abbasi, K. S., \& Pervaiz, S. (2012). The Effect of Customer Trust on Customer Loyalty and Customer Retention: A Moderating Role of Cause Related Marketing. Global Journal of Management and Business Research, 12 (6).

Setiawan, H., \& Sayuti, A. J. (2017). Effects of Service Quality, Customer Trust and Corporate Image on Customer Satisfaction and Loyalty: An Assessment of Travel Agencies Customer in South Sumatra Indonesia. Journal of Business and Management (IOSR-JBM), 19 (5), 31 - 40. https://doi.org/10.9790/487X-1905033140

Sultan, P. (2018). How service quality affects university brand performance, university brand image and behavioural intention : the mediating effects of satisfaction and trust and moderating roles of gender and study mode. Journal of Brand Management. https://doi.org/10.1057/s41262-018-01313

Unidha, M. (2017). The Effect of Service Quality on Trust and Loyalty for Giant Customers in Malang City. Arabian Journal of Business and Managemet, 7 (5), 5 - 9.

Yoo, M., \& Bai, B. (2013). International Journal of Hospitality Management Customer loyalty marketing research: A comparative approach between hospitality and business journals. International Journal of Hospitality Management, 33, 166 - 177.

Ziaullah, M., Feng, Y., \& Akhter, S. N. (2014). E-Loyalty: The influence of product quality and delivery services on e-trust and e-satisfaction in China. International Journal of Advancements in Research \& Technology, 3 (10), 20 - 31. 